\title{
Mission versus ethics in 1 Corinthians 9? 'Implicit ethics' as an aid in analysing New Testament texts
}

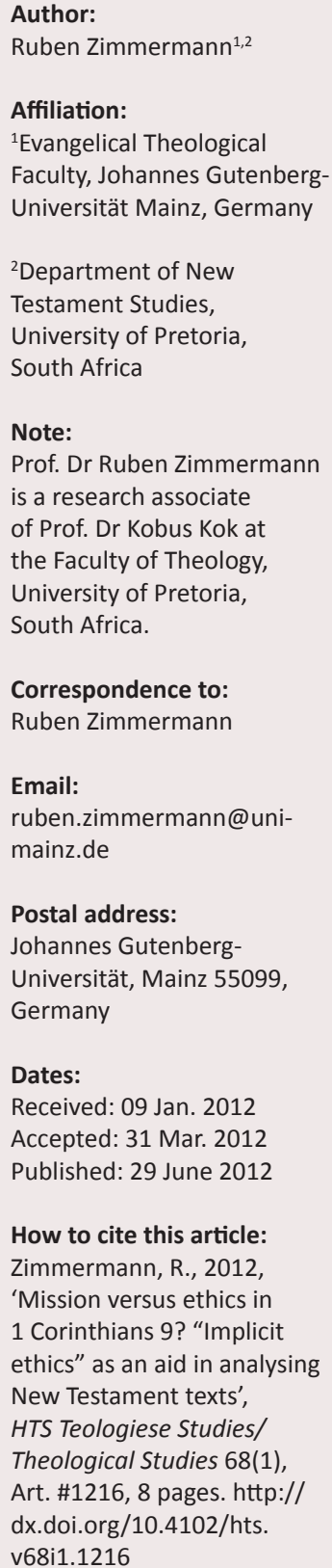

Correspondence to:

Ruben Zimmermann

Email:

ruben.zimmermann@uni-

mainz.de

\section{Postal address:}

Johannes Gutenberg-

Universität, Mainz 55099,

Germany

Dates:

Received: 09 Jan. 2012

Accepted: 31 Mar. 2012

Published: 29 June 2012

How to cite this article: Zimmermann, R., 2012,

'Mission versus ethics in 1 Corinthians 9? "Implicit ethics" as an aid in analysing New Testament texts', HTS Teologiese Studies/ Theological Studies 68(1), Art. \#1216, 8 pages. http:// dx.doi.org/10.4102/hts. v68i1.1216

C) 2012. The Authors. Licensee: AOSIS OpenJournals. This work is licensed under the Creative Commons Attribution License.
The central question concerning how mission and ethics are related arises within the context of the understanding of ethics itself and in this way often leads back to the familiar 'indicative and imperative' model. This oversimplified approach, however, is ultimately inadequate for the Pauline ethic in general and for the particular problem concerning mission and ethics. In this article, 1 Corinthians 9 was drawn upon as an example for the 'implicit ethics' model, a model which allows for a more nuanced presentation of the grounds and justification for behaviour and action. Through this approach it became clear that the proclamation of the Gospel does not have to be 'unethical'; rather, it could be located and understood within the realm of the Pauline reflection on conduct. This, in turn, justified speaking of an 'ethic of missions (activity)' in Paul.

\section{Introduction}

\section{Mission and ethics - A first approach}

Paul was a missionary. There is little doubt concerning this assessment within New Testament (NT) scholarship. ${ }^{1}$ Paul was the founder of Christian congregations in Thessalonica, Philippi and Corinth and possessed a zealous interest not only for the existence, but also for the growth, of these communities (e.g. 2 Cor 11:2-3; Phlp 1:6).

But was Paul, at the same time, an ethicist? The Pauline letters are certainly not ethical treatises in the sense of the Nicomachean Ethics of Aristotle. However, the apostle does not simply offer concrete advice on behaviour, but he is also reflecting and arguing why a certain way of acting is better than another. His arguments can be understood as general reflections on behaviour. Thus we may find at least an 'implicit ethics' within Paul's writings.

The question remains, how do mission and ethics belong together? Is there any connection at all? Is it the Christians' different way of life, which convinces the outside world more than missionary preaching? Or does Paul simply want to clarify ethical problems within the community itself, having no interest in doing missionary work with an ethical conception? In other words: Can one say that ethics is something for the inner circle of the church, whereas mission, by contrast, is addressed to the outside world? Behind this we detect a contrast between ethics and theology which, for an extended period of time, dominated research on Paul's writings. Many scholars divided the letters, for example, to the Galatians and to the Romans, into two parts: firstly a section on theology, secondly a section on ethics. With regard to our focus we may narrow the division down to, firstly, theology as a missionary act telling the Good News to everyone; secondly, ethics as a pastoral act regulating the daily life of the congregation. Mission versus ethics?

\section{Mission versus ethics in 1 Corinthians 9}

In 1 Corinthians 9 Paul addresses questions concerning the lifestyle of early Christian missionaries. He must defend himself, as explicitly stated in 1 Corinthians 9:3, against the accusations of certain opponents who questioned his lifestyle. Concretely stated, the issues concern 'eating and drinking' (v. 4), the 'right, to be accompanied by a believing wife' (v. 5), and 'working for a living', that is the support of missionaries by the congregation.

These issues simply put, concern practical questions of living. Furthermore, that which makes arguments and discussion necessary is the fact that some controversy existed about how to answer such questions. Paul speaks of 'us' as opposed to 'the other apostles' (v. 5). Apparently there are different, even opposing lifestyles of other apostles who raise this practice to the level of a norm and thus require Paul - because of his own practices - to defend himself. ${ }^{2}$

1.See, for instance, the discussions in Peerbolte (2003), Plummer (2006), Ware (2005), and the survey in Kok (2012).

2.See for a plausible reconstruction of the problem Theißen (1979:201-230), Pratscher (1979), and more recently Harnisch (2007:31-32) 
At its root the question actually concerns: What is right conduct? What is good and correct to do, and why? Whoever enters into a dispute concerning the reasons for proper action begins 'to do ethics'. Ethics becomes necessary precisely and especially in situations involving conflict where it is not a priori clear what the right, or the good course of action is in that situation. At this point the justification, explanation and communication concerning presuppositions and criteria for evaluating behaviour becomes necessary.

Paul enters into such a discussion in 1 Corinthians 9. He wrestles with and pursues reasons and arguments that legitimate his conduct, and in this way he is 'doing ethics', or, put another way, he is an ethicist.

Let us consider verses 7-15 more closely. Paul offers two lines of argument, presented in a long series of rhetorical questions, to justify the right to financial support: Firstly, Paul points to examples drawn from 'secular' life and his rhetorical questions seek obvious and undisputed answers. For example, verse 7a: 'Who at any time pays the expenses for doing military service?' Answer: Nobody. It is selfevident that a soldier, vinedresser, or shepherd receives a salary or may live off that which his or her labour produces. This reasoning draws on the ethos of everyday life in order to be convincing. At the same time however, Paul does not offer only human logic (menschliche Logik ${ }^{3}$ ), but draws a similar conclusion in referring to the 'Law of Moses' and citing Deuteronomy 25:4. The same principle of the right to support in an agrarian context is also set forth in the Torah. This first line of argument however, ends with Paul indicating that he declined to invoke this right. In verse 13 the apostle returns to the, from his perspective, presumably successful use of rhetorical questions: that which is true for secular work can be applied to religious service. The right to support is also valid for priests and those who serve at the altar. They may secure their livelihood through their service in the temple. This argument is also concluded with a citation; however, in this instance it is not drawn from the Torah, but rather from Jesus. One of the very few citations of Jesus' words by Paul occurs here. This logion too confirms the maxim that a worker may receive wages. Yet, once again the final statement is a refusal to lay claim to such rights (1 Cor 9:15).

Paul in no way disagrees with the right to support. On the contrary, he supports this right through ethical reflection and secures it with appeals to ethos, scripture, and Jesus' words. The carefully constructed ethical argument, however, is discarded based on the proclamation of the Gospel: the gospel alone is the criterion and goal for Paul. In 1 Corinthians 9:12 Paul already makes reference to the 'gospel of Jesus Christ'

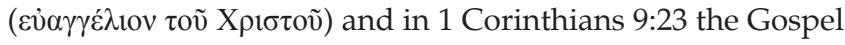
is invoked in the summarising conclusion.

Are thus, all behavioural maxims such as Torah, Jesus' words, the ethos of daily life discarded when the preaching of the

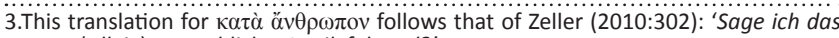
etwa (allein) menschlicher Logik folgend?' gospel, when mission is at stake? More pointedly: is ethics superfluous when the issue is mission? Is 1 Corinthians 9, in this way, a perfect example of sophisticated ethics ultimately lagging far behind theology? Mission versus ethics?

One seems to be able to find precisely such evaluations in some commentaries. Paul is not an ethicist, he is a missionary whose ends justify the means and every long-established or carefully argued rationale is simply overthrown when the issue is the proclamation of the gospel.

In 1 Corinthians 9:19-23 there is a recurring i $v \alpha \ldots \kappa \varepsilon \rho \delta \eta ் \omega$. [so that I might win]; expressed concretely in 1 Corinthians 9:22 ('that I might by all means save some'). Therefore, mission at every price, even at the cost of ethics, the cost of carefully established and universally applicable principles? Mission at the cost of argument and communication?

\section{The model of 'implicit ethics'}

In the light of this constructed opposition one could be tempted to return to the traditional indicative-imperative model that was long used as the foundation for considering Paul's reflections on behaviour. Firstly, the indicative of mission and then, at a considerable distance, the imperative of ethics. In the following section of this article I will discuss the limitations and my criticisms of the indicative-imperative model and then present my own model of 'implicit ethics'. In this way it will become clear that the opposition 'theology (or here: theology of mission) versus ethics' not only misses the point of the subject matter of Paul's letters, but also of my method of textual analysis.

\section{The limitations of the indicative- imperative model}

Rudolf Bultmann, in his article entitled 'Das Problem der Ethik bei Paulus' ([1924] 1967), introduced the terminology 'indicative and imperative' in order to attempt to describe a fundamental challenge. How can theology and behaviour be brought together in Paul?

On the one hand, it is indisputable that the letters of Paul prompt a specific type of behaviour, that is, an imperative of behaviour. ${ }^{4}$ On the other hand, the unconditional promise of salvation, the grace without 'works of the law', that is, the doctrine of justification, was developed as the core of Pauline theology. Is there not, in this way, an irreconcilable contradiction between the imperative of behaviour and the indicative of salvation?

This is not the place to speak further of the subsequent reception of this model as I, amongst others, have sought to do elsewhere (cf. Dunn 1998:626-631; Parsons 1995:217-249; Zimmermann 2007:259-284). Nevertheless, there is a clear trend towards wanting to abandon the indicative-imperative model as less than satisfactory and too easily misunderstood (in the German-speaking realm I mention only Backhaus

4.See Romans 12:20; 13:3, 10, 14; 1 Corinthians $16: 10$; 2 Corinthians 13:7; mostly

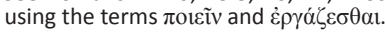


2000:9-31; Blischke 2007; cf. also Horrell 2005:10-15; Schnelle 2003a:109-131, 2003b:62-644). Together with my colleague in Mainz, Friedrich W. Horn, I edited a volume of collected essays entitled Jenseits von Indikativ und Imperativ in which various criticisms of the indicative-imperative model were brought together, whilst also offering constructive alternatives to the model (Horn \& Zimmermann 2009). The criticisms include different dimensions (cf. Zimmermann 2007:264f.):

\section{The text itself:}

- The classification of certain content to the speech modes 'indicative' and 'imperative' cannot be established in the text. Paul can formulate the same statements as 'indicative' and as 'imperative.' For example, 'put on Christ' in Galatians 3:27 (indicative) and in Romans 13:14 (imperative). ${ }^{5}$

\section{Appropriateness:}

- The indicative-imperative pattern introduces an artificial division that retrospectively pulls apart a unity as presented by Paul.

- The model suggests a temporal or logical priority, of whatever kind, of the indicative before the imperative.

- The pattern is reductionistic and inflexible and therefore contradicts the dynamic and multifaceted Pauline rationale for behaviour.

\section{Theology:}

The formulation of indicative and imperative leads to unsolvable aporiae with a view towards the validity of Pauline soteriology:

- Does God's gift of salvation have to be validated or perfected by humanity? Is it therefore in some manner incomplete or limited without human action?

- What type of (negative) soteriological quality is assigned to the imperative?

4. Speech and moral philosophy:

- Indicative and imperative are metaphors with which no precise, ethical description of the Pauline rationale for action is possible.

- If the terms are conceptually evaluated, their moralphilosophical attribution is problematic since if an imperative ('what ought to be') is derived from an indicative ('what is') the so-called 'naturalistic fallacy' (Moore 1970:41-52) is committed.

Returning to 1 Corinthians 9 and the problem of mission and ethics, in the first section of this article I constructed a confrontation between mission and ethics. The resultant attribution: 'Mission = Gospel or Theology = Indicative' and 'Ethics = Imperative' reveals itself, upon closer consideration, as inadequate or even entirely wrong. For Paul, mission is

5.See 1 Thessalonians 5:8/Romans 13:12 (weapons); 1 Corinthians 5:7b/1 Corinthians 5:7a.8 (leaven); 1 Corinthians $6: 11 / 1$ Thessalonians 4:3f. (sanctification) 2 Corinthians 5:18 f./2 Corinthians 5:20 (reconciliation); Romans 6:2.10/Romans $6: 11$. (redemption from sins) not an indicative of salvation and therefore cannot simply be linked to theology and the salvific promise. Within the term 'mission' one already finds, etymologically speaking, the 'sending' (missio), a clear activity. In the specific case in 1 Corinthians 9 one finds a definitive action (even refusing to act is an act!) on the part of Paul in order to 'do missions'. Philosophically speaking, the difference between 'doing' and 'refraining from doing' is often essentially irrelevant as far as ethics is concerned (cf. Birnbacher 1995). In each instance one is dealing with a behaviour that is operating within an ethical argument and evaluation framework. Thus, Paul on the one hand, justifies his 'mission occupation' by referring to his refusal of certain activities (eating, drinking, taking along a wife, accepting support), and on the other by pointing to concrete action. The long list of missionarische Anpassung (cf. Zeller 2010:315) shows Paul to be an active agent: he enslaved

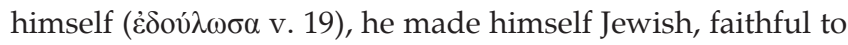
the law, apart from the law, weak (vv. 19-22). Finally, the

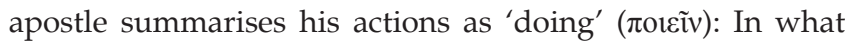
way now are behaviour and belief allocated, mission and ethics related to each other? Acting not 'from' or 'out of' the gospel, but 'for' or 'on' the gospel? 'So that I may win', even 'save'? Is Paul himself 'saviour' in a synergistic sense? Imperative before and for the indicative?

At least this must now be clear: a simplistic classification of indicative and imperative breaks down based on the example of 1 Corinthians 9. It also reaches its limits in the problem of mission and ethics. Mission assumes action and behaviour, even if this acting is the passing on of the message of salvation, of the gospel.

The actual problem of indicative and imperative thus actually becomes more acute. If God's salvific promise is fundamentally valid, and is not conditioned by human action, then any acting and mission becomes superfluous. God alone justifies, the indicative removes the imperative of the missionary occupation and in a strict sense even forbids it.

Thus we can confidently affirm: in the light of both general and specific criticisms, within New Testament scholarship and exegesis one should once and for all bid adieu to the indicative-imperative model as the explanatory framework for the correlation of theology and ethics in Paul. ${ }^{6}$

\section{The analytical model 'implicit ethics'}

How then, can one describe and delineate ethics and theology? Must we refrain from offering a descriptive assessment of ethics? Or are we once again questioning whether ethics even exists in Paul?

We have seen that precisely in seeking to elucidate Paul's 'lifestyle', his 'lifestyle' is clearly based on decisions concerning behaviour. Furthermore, in the concrete formulations we can recognise that there are certain purposes (iv $\alpha$...) in Paul's

6.Wolter (2009:121-169); Wolter (2011:310-338) more recently wanted to point out the strength of the indicative-imperative-scheme, but did not discuss or address the arguments questioning the model. 
'doing' or 'not doing'. He acts based on certain behavioural maxims and certain goals. Concretely stated: his mission activity, established and justified in this way, is part of an ethical discourse.

In order to be able to better recognise and appreciate this ethics, I have elsewhere developed the model of 'implicit ethics' (cf. Zimmermann 2007:274-276, 2009) which I would like to present briefly here before applying it to 1 Corinthians 9 .

In order to avoid misunderstanding, it is important to reiterate that this model presents a methodological approach with which one is able, as precisely as possible, to capture the text-based behavioural rationale and underlying value system of Paul (as well as other texts).

In no way is the model conceived of as one in which the theological basis of Pauline ethics is to be undermined in the sense of ethics versus theology. At the same time however, it should become apparent that, for example, grace, Jesus' words, et cetera are identified as norms for conduct alongside and in connection with other norms. These norms do not stand next to each other, rather, they arise in a certain competition with each other or are arranged in a system of prioritisation. Yet, precisely in this way the specifics of a value system can be recognised in which the Torah is not sweepingly or completely denigrated, as suggested in the over-simplifying indicative-imperative model.

In order to do justice to the nuanced differentiation of ethical discussion (also in the philosophical context), I have selected eight varying perspectives, which I have explained elsewhere (Zimmermann 2010:24-28, 2009:403-416). To that end the dimensions are simply mentioned here:

1. Linguistic form: Which linguistic form does the ethical statement take?

2. Norms and maxims for action: Which leading norms and maxims for action are mentioned?

3. History of traditions of individual norms or moral instances: In which traditional and contemporary context do these norms exist?

4. Priority of values: Which inner context of different norms is produced? Which emphasis of norms, which hierarchy of values can be recognised?

5. Ethical argumentation or structure of motives: According to which internal structure of motives, according to which ethical argumentation does the ethical judgement take place?

6. The moral agent: Who is the ethical subject or the carrier of ethical judgements? Which factors constitute the ethical subject?

7. The resulting ethos as lived: Which concrete ethos corresponds to or contradicts the ethical argumentation?

8. Field of application: Which field of application of a norm is mentioned?

\section{The 'implicit ethics' in 1 Corinthians 9 Linguistic form}

What is the speech form of the reflections in 1 Corinthians 9?

On the intra-textual level we can recognise an interrogative

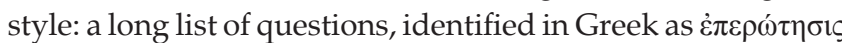
dominates the speech. I would like to extrapolate on this point only with regard to the opening section of the chapter. Paul begins with four questions (1 Cor 9:4), which thematically anticipate the following and can therefore rightly be labelled, within the context of ancient rhetoric, as the exordium [introduction, exposition] of the speech (cf. Harnisch 2007:25). In this way the question, 'Am I not free?' (v. 1a) can be understood as anticipating the section in 9:19-23 that is also introduced with the significant term $\dot{\lambda} \lambda \varepsilon v \dot{\theta} \theta \rho \rho \varsigma$. The question 'Am I not an apostle' (v. 1b) is suitable as the heading for the section 9:4-18, in which the question of the apostle's conduct is debated. In this way, the two questions stand as a chiasm to the order in the extended discussion, a point that has often been recognised in the scholarly literature (cf. Dautzenberg 1969:228; Harnisch 2007:27; Jeremias 1966:289f.).

On the intertextual level we can pursue the question of the form and genre of the text. The text itself offers a clear hint in verse 3 in that Paul here utilises the term 'apology'. Along with many other exegetes, I understand the verse-concluding

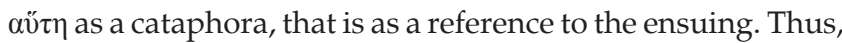
the entire following discussion is placed under the heading

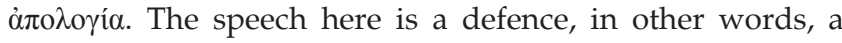
forensic speech. ${ }^{7}$ Correspondingly, one would expect that Paul would refute the accusations of his opponents and thus defend his conduct and his apostleship. And yet, the text apparently does the opposite. Paul defends and proves, rather exhaustively, the right to support and therefore agrees completely with the perspective of his opponents. In order to do so, the form of negative rhetorical questions is chosen with the aim to achieve an agreement on the part of

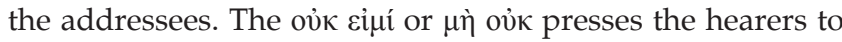
respond: 'But of course he has the right, it is patently obvious that a vinedresser or a priest receives support!'

At this point we have arrived at the third level of the linguistic analysis, the level that I have called 'extra-textuality'. What is the pragmatic, the speech act if you will, of this text?

Through his rhetorical proof, Paul brings about the agreement of his addressees concerning the right to support. And yet, instead of following with the corresponding conclusio, that is, something like 'because the right to support has been proven, make sure that from now on you provide me with support!', Paul declares his refusal of this right. In this way it becomes clear that the intention cannot really be to prove

7.So, for instance, Lührmann (1986:309, n. 51). For a different view, see Mitchel (1991:246): '1 Corinthians 9 is no defense speech by Paul.' 
the right to support. Instead, Paul 'irritates' his addressees with his refusal and appeals for their insight into a higher

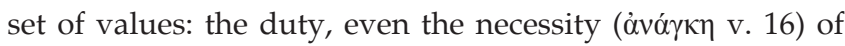
proclaiming the gospel is more important than the duty to support. The mention of rights and duties, thus indirectly invoking values and norms, leads to the second area of focus.

\section{Norms and maxims for action}

Within his argument Paul refers to various different values and norms. A reduction to a single, normative 'salvation indicative' cannot do justice to the text, since Christ, the gospel, or grace are already different norms. With the identification of particular norms (e.g. the Torah) an entire concept of ethical criteria is recalled. This assumes a consensus concerning the recognition of these norms by all parties involved in the communication so that there is no need to justify each one individually. Thus, it is not necessary to further underscore 'freedom' as an ethically relevant norm or that the 'Torah' portrays a particular normative instantiation.

Firstly it is necessary to list descriptively the norms used in 1 Corinthians 9, which is done in Table 1.

\section{History of traditions in context}

The various norms listed above gain their ethical value primarily through the traditional discourse in which they have been established. For this reason it is necessary to consider the tradition-history of the norms in order to be able to determine how a norm is utilised in a particular text. Here, and in an exemplary fashion, I will consider only the first norm, freedom $(\dot{\varepsilon} \lambda \varepsilon v \theta \varepsilon \rho i \alpha),{ }^{8}$ which is mentioned in both verses 1 and 19 and thus functions as an inclusio for the chapter. In 1 Corinthians, the term $\dot{\varepsilon} \lambda \varepsilon v \theta \varepsilon p i ́ \alpha$ occurs once (1 Cor 10:29) and $\dot{\varepsilon} \lambda \varepsilon v \dot{\theta} \theta \varepsilon \rho \varsigma$ six times (1 Cor 7:21f., 39; 9:1, 19; 12:13, cf. also one instance of $\dot{\alpha} \pi \varepsilon \lambda \varepsilon v \dot{\theta} \theta \varepsilon \rho \varsigma$ in 1 Cor 7:22). Furthermore, there are several instances where 'freedom terms' are utilised, even if the precise word does not appear (e.g. 1 Cor 6:12; 10:23: $\pi \alpha \nu \tau \alpha ~ \check{c} \xi \varepsilon \sigma \tau \imath v$ 'all things are lawful'). In almost every instance, the use of these terms stands in material relation to

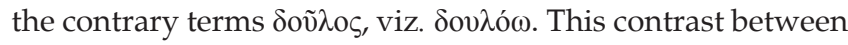
slavery and freedom is traditional and constitutive for the use of the term in the Hellenistic tradition.

Through this tradition-historical perspective it is possible to evaluate Paul's recourse to 'freedom' as an ethical norm. Through the rhetorical questions Paul reveals that he and, in all likelihood, his addressees know the populist conception of external freedom in the sense of freedom from restraint and in the sense of licentiousness (1 Cor 6:12; 10:23; cf. 9:1). Yet, Paul, like in Stoicism, relocates freedom to the internal realm. It is not however autonomy and self-control that confer this inner peace as it is for the Stoics, but rather bondage to Christ.

8.For discussion of this term, see Schlier (1935:484-500); Vollenweider (1989); Malherbe (1995:231-255); Dautzenberg (2001:57-81); and Theißen (2002:357-368).
TABLE 1: Norms and maxims for action in 1 Corinthians 9.

\begin{tabular}{|c|c|}
\hline $\begin{array}{l}\text { Norms and/or leading maxims } \\
\text { (in the order of first occurrence) }\end{array}$ & Occurrences in 1 Corinthians 9 \\
\hline 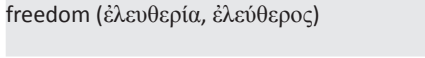 & $\begin{array}{l}1 \text { Corinthians 9:1, } 19 \text { (see also } 1 \text { Cor } \\
\text { 7:21f.; 7:39; 10:29) }\end{array}$ \\
\hline 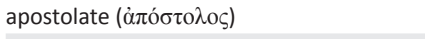 & 1 Corinthians 9:1.2, 5 \\
\hline 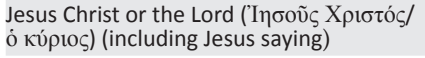 & 1 Corinthians 9:1(bis), 2, 5, 12, 14, 21 \\
\hline 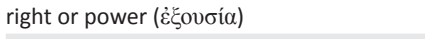 & 1 Corinthians 9:4, 5, 6, 12(bis), 18 \\
\hline 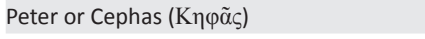 & 1 Corinthians 9:5 \\
\hline 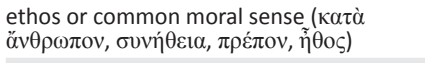 & $\begin{array}{l}1 \text { Corinthians } 9: 7 \text { (see also } 1 \text { Cor } 8: 7 \\
11: 13,16 ; 15: 33 \text { ) }\end{array}$ \\
\hline Torah-law (of Moses) (vó $\mu$ os) & $\begin{array}{l}1 \text { Corinthians 9:8-10, 20, } 21 \text { (see also } \\
14: 34 ; 15: 56 \text { ) }\end{array}$ \\
\hline flesh - spirit ( $\sigma \alpha ́ \rho \xi-\pi v \varepsilon \tilde{u} \mu \alpha)$ & 1 Corinthians 9:11 \\
\hline 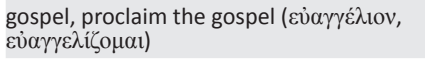 & $\begin{array}{l}1 \text { Corinthians } 9: 12,14 \text { (bis), } 16,18 \text { (ter), } \\
23\end{array}$ \\
\hline 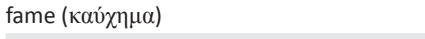 & 1 Corinthians 9:15, 16 (see 5:6) \\
\hline affects or emotions, e.g. necessity (ảvó $\gamma \kappa \eta)$ & 1 Corinthians 9:16 (see 7:26; 7:36) \\
\hline reward or fee $(\mu 1 \sigma \theta \dot{\varsigma} \varsigma)$ & 1 Corinthians 9:17, 18 \\
\hline 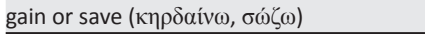 & 1 Corinthians 9:19, 20(bis), 21, 22, 23 \\
\hline
\end{tabular}

This christologically motivated 'paradoxical' understanding of freedom is particularly evident in 1 Corinthians 7:20-23. The free person is a slave of Christ just as the slave is a freed

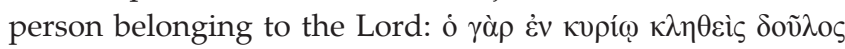

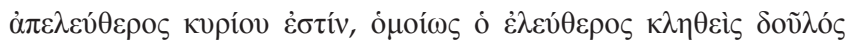

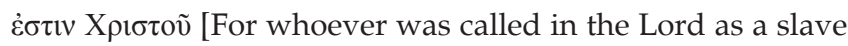
is a freed person belonging to the Lord, just as whoever was free when called is a slave of Christ. \{1 Cor 7:22\}].

According to the Pauline understanding therefore, the freedom of the Christian is twofold: it is a freedom from norms that could enslave a person (e.g. the desires as in 1 Cor 6:12-20 or the demand for circumcision in Gl 5). At the same time, it is a freedom to a new bondage in the relationship with Christ as it is vividly corporally formulated in 1 Corinthians 6:17-20 (ко $\lambda \lambda \alpha$ ó $\mu \alpha$ ). The conception of freedom in 1 Corinthians 9 is also to be understood in this way: Paul is free from every duty to support even as he is financially free, that is, 'independent' from the community. But 'though he is free with respect to all he has made himself a slave to all' (see v. 19), so that he may win some for the gospel. In this way freedom is subordinated to the gospel.

\section{Priorities of values}

Clearly, freedom is not an absolute value, but rather exists within a hierarchy of values, being slotted above some and below other values. Paul does not receive ethical norms uncritically or simply in a contrastive way, instead they are modified within his arguments, occasionally relativised or criticised, placed in relation to others and hierarchically ordered. That is, they are located within a comparative axiomatic and values ethics. In considering more closely this priority of values in verses 7-14, we can recognise a clear hierarchy of values in the rhetorical design of this section. According to Sundermann (1996:243, 248; also Harnisch 2007:34), one can outline the verses identified as probatio [proof] according to rhetorical aspects: 
Rhetoric disposition

9,7-12ab refutatio I (three arguments)

9,7 first argumentum secundum hominem

9,8-10 argumentum secundum legem (Dt 25, 4)

9,11.12ab argumentum a comparatione

9,12c-e first summary as correction

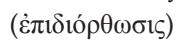

9,13f. refutation II (two arguments)

$\begin{array}{lll}\text { 9,13 } & \begin{array}{l}\text { second argumentum } \\ \text { secundum hominem }\end{array} & \text { ethos in sacral } \\ \text { 9,14 } & \text { argumentum secundum } & \text { Jesus saying }\end{array}$
praeceptum Domini

9,15a second summary as correction

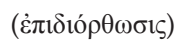

If one attempts to discover an implicit hierarchy of values within the rhetorical organisation of these norms, one will detect that custom and 'everyday' morality is referred to first, whereas vónos and $\lambda$ ó respective subsections with a progressive purpose. If one also recognises the climax within the entire passage, then one can again perceive the higher value of the sacred over the profane and Jesus' words over the Old Testament law. The Jesus logion marks the 'Höhepunkt in der Argumentation' (cf. Galitis 1981:135; Wolff 1990:26). ${ }^{9}$ A rhetorical-compositional analysis of the section also reveals the hierarchy of values of the apostle that stand behind the progression of the argument. This hierarchy, with respect to the previously mentioned norms, is organised as follows: Ethos (profane - sacred) > Torah > The Words of Jesus (Horrell 2005:214f.; cf. Schrage 1995:295, 308).

\section{The ethical Logic - argumentation - structure of motives}

Yet, what significance do these norms have within the 'implicit ethics' of Paul? Does the refusal of the right on the part of Paul render the above-mentioned norms invalid, making them, in principle, worthless? Is this one more demonstration that for Paul, the contemporary ethos, Jewish law, and even the words of Jesus (viz. a statement of the earthly Jesus, cf. Q/Lc 10:7) have come to the end as normative entities in the light of the gospel?

Even though Paul declares his personal renouncement, he in no way contests the validity of the enumerated norms. Quite the contrary. In my opinion, this becomes evident through

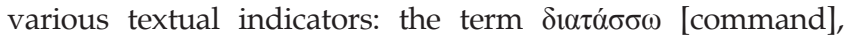
already utilised in the Jesus logion underscores the authority and binding nature of this word, whose lasting validity is further supported through the use of the aorist and the kuriostitle (cf. Schrage 1995:309). Moreover, the validity of the norms is also underscored in Paul having to defend himself against their persuasiveness in verse 15: 'But I have made no use of any of these rights, nor am I writing this so that they may be

9.Pratscher (1979:285) states "als letzte und schwerste Waffe [wird] ein Herrenwort ins Feld [geführt].' applied in my case.' Above all, the inner logic of the refusal speaks against any denigration. Only with the continuing validity of the named behavioural norms is the decision by Paul to distance himself from them truly a refusal.

For Paul, however, there are further norms at play that are valued more highly and justify his renunciation. Decisive here is $\dot{\varepsilon} \lambda \varepsilon v \theta \varepsilon \rho i \alpha$, which is already mentioned in the introductory

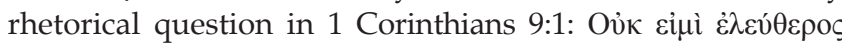
(cf. Popovic 2003). The freedom of the apostle becomes visible, in the first instance, in his ability to refuse financial support. Paul is, ethically considered, free to subordinate the norms mentioned in 1 Corinthians 9:7-14 to higher values. This freedom though, does not become a deontological norm in itself that necessarily must be obeyed. In no way can freedom in the populist sense be confused with an autonomous unrestricted life. Paul makes the heteronomous character of his 'paradoxen Freiheitsverständnisses' (Theißen 2002:364) unmistakably clear. He does not act according to an autonomous will, but is under - paradoxically formulated 'necessity' (1 Cor 9:16f.) ${ }^{10}$ in his freedom namely, the necessity to proclaim the gospel of Jesus Christ. Christian freedom arises out of an 'un-freedom', namely the bond to Christ. At the same

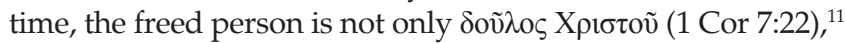
but can also enter into - following the example of Christ ${ }^{12}$

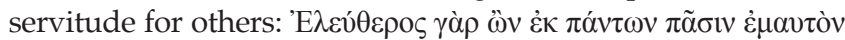
$\dot{\varepsilon} \delta$ ov́ $\omega \omega \sigma \alpha$ (for though I am free with respect to all, I have made myself a slave to all, 1 Cor 9:19). In the ensuing verses (1 Cor 9:20-22) the precise nature of this servitude is made concrete: Paul is Jew, Greek, under the law, outside the law, in short: he has become all things, in order to save some.

From an ethical vantage point this means that 'freedom' as an end is teleologically set forth towards the goal of gospel proclamation and mission. Thus, freedom - as also indicated in the following: 1 Corinthians 6:12 and 10:23 - finds its determination and its limitation in particular series of action. In 1 Corinthians 9:19-23, the passage under consideration here, the behavioural goal of the freedom norm is 'so that I might

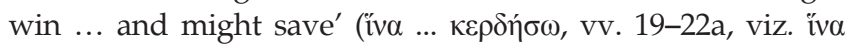

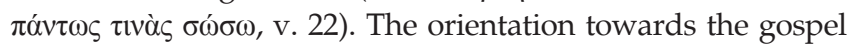
is found at the end of the section as a programmatic statement:

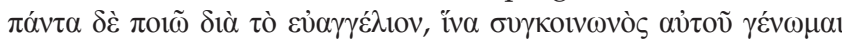
(1 Cor 9:23).

Mission and a gospel orientation are therefore not set against ethics, but rather become the highest goal in the sense of the aspiration in a teleological ethic, which then motivates conduct. $^{13}$

10.Theißen (2002:358) to a certain extent rightly speaks of a 'Gegenaffekt'.

11.Bryon (2003) has correctly noted that one does not find the designation $\delta$ oṽ $\lambda \circ$

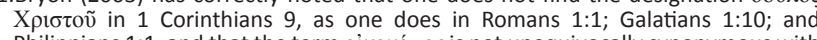

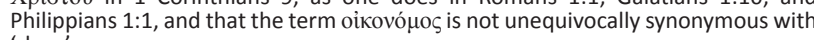
'slave'.

12.The intended Imitatio Pauli in 1 Corinthians 9 is rightly, with reference to 1 Corinthians 11:1, tied back to the Imitatio Christi. If the Corinthians follow Paul's example, then ultimately they are following the example of Christ. So Horrell (2005:214-222); cf. also the general comments by Merk (1998:302-336).

13.Significantly, Hays (1996:43) notes concerning the 'telos': 'The telos of such action is not just to enhance personal virtue and humility but also to secure the unity of the Community in Christ.' This goal is expressed concretely, for example, in taking into account the conscience of the weak (cf. 1 Cor 8:13: so as not to cause a brother

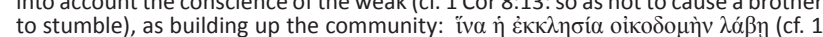

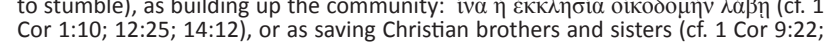
Cor $1: 10 ; 12: 25$ 
Once again, mission is not a formal end in itself but stands in a referential context as seen in the iv $\alpha$-sentence. Ethically regarded, the gospel is altruistically determined in the sense of saving others, that is, the building up of the community.

At this point I would like only to briefly consider the final three aspects.

\section{Moral agent}

Firstly, the ethical subject. Whom does the ethical argument concern? Who is the decision maker and the one deciding conduct?

That this question is anything but self-evident is already clear in the Torah citation concerning the ox treading out the grain (Dt 25:4) in 1 Corinthians 9:9. It is debated within New Testament exegesis whether the point here, as apparently in the original meaning of the saying, is a statement about the protection of animals, which portrays the ox as an ethical subject, or whether we are confronted with a metaphorical reapplication that has humanity in view (cf. Brewer 1992). It seems to me that the latter is more likely in the light of Paul's three questions in 9:9c, 10a and b.

\section{Resulting ethos as lived}

Even, if making the lived 'ethos' the centre - as advocated by Michael Wolter in his approach (cf. Wolter 2009) - must be criticised, the question concerning the referentiality of the ethical statements in the text to the extra-linguistic reality is legitimate. In other words, how are the ethics in the text and ethos in reality of the (original) communication connected?

Gerd Theißen attempted to show that the claimed norm in the text, namely, that a 'wandering missionary' would receive support, is not at all self-evident. In fact, he contends that the contrary, that is, the full voluntary nature of such work can be shown to be the ethos. It was not at all commonplace to receive support for proclaiming. ${ }^{14}$ The opponents of Paul first had to establish this right and raise it to the status of a criterion for apostleship.

Furthermore, we can critically question Paul's claimed financial independence in that, according to 2 Corinthians 11:8 and Philippians 4:15, he did in fact receive support from the congregations.

The praxis that can be gleaned from other texts could, in both cases contradict the ethical norms claimed in the text. At the very least, it relativises the right.

\section{Adressee - field of application}

Finally, the question can be asked concerning the ultimate point of, or goal in Paul's argument. Who are the actual addressees of this ethical discussion? Is the point Paul's own ethical justification? Hardly, as already evidenced in the appeal of the text. But towards whom then, is the appeal concerning conduct directed? Is Paul's point an attempt to persuade the 'other' apostles of the legitimacy of his own apostleship, which they have doubted?

14.See Theißen (1979).
This discourse is embedded in 1 Corinthians $8-10,{ }^{15}$ that is, in the debate concerning meat sacrificed to idols, which makes it possible to recognise that Paul is ultimately not concerned either with himself, or with criteria for apostleship but rather the problem with, or the perspective taken towards, meat sacrificed to idols and the resulting role of the strong (and weak) in Corinth. As then explicitly stated in 1 Corinthians 11:1, the strong should follow Paul's example; they are the actual 'ethical addressees' in 1 Corinthians 9. They should not insist on 'their rights' and employ their 'inner freedom' in order to serve others.

\section{Epilogue: The 'implicit ethics' in 1 Corinthians 9 - and: What about ethics and mission?}

To conclude: what has been gained through this nuanced analysis? What does the method of 'implicit ethics' have to offer? What does it contribute to the question with which I began concerning mission and ethics?

I hope that at least one thing has become clear, namely that 1 Corinthians 9 reveals a complex, multi-stage ethical argument that cannot be reduced to a simplistic indicative and imperative framework. In addition, a nuanced perspective guards against missteps and errors in the ethical analysis. Deontological norms such as convention, the Torah, and the words of Jesus are not rendered null and void for Paul. Whoever judges Paul in the category of a simplistic value classification scheme (i.e. valuable - valueless) fails to recognise the positive value that the mentioned normative instances continue to have, and indeed must continue to have for Paul's argument. Within a comparative axiology, however, their scope becomes limited and they become teleologically subordinated to particular goals. In 1 Corinthians 9 Paul argues along the lines of a 'practical ethics' or an 'integrative ethics' (cf. Krämer 1995) that intertwines deontological and teleological thinking.

Fundamentally valid norms, based on which particular behaviour can be justified deductively, do exist. This is the case for the rationale of the right of a labourer to a wage as well as with respect to the heteronomous religiously constructed norm of the proclamation of the gospel. At the same time, the ethical evaluation of behaviour must also keep the consequences of that behaviour in view. In this way, the ethical value of certain conduct is determined through its placement within the integration of normative conduct and the results of such conduct.

Since Paul's behavioural justification explicitly functions as an example for the conduct of the Corinthians in the conflict concerning meat sacrificed to idols, one can also conclude that the particular arguments have appealed to a broader, and in a certain sense even universal, validity. This fact is also significant for the evaluation of mission.

15.As Nasuti (1998:246) observes, 'The chapter is now widely recognised as an integra part of the discussion of meat sacrifice to idols found in chaps. 8 and 10.' Similarly, Mitchell (1991:247); Fotopoulos (2003:223); Popovic (2003:415-419); and Horrell (2005:170). 
The proclamation of the gospel was for Paul, more significant than the right to support. Yet, even the gospel is neither an end in itself, nor subjugated to Paul's disposition. The

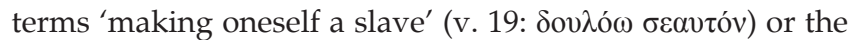

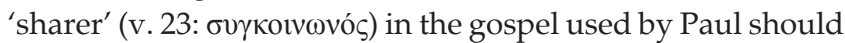
be remembered by certain overzealous missionaries in our own day. The teleological and altruistic ethic of Paul is not conducive for militant evangelisation strategies.

And so I return to the opening question: how are mission and ethics connected? Do mission and ethics have to be distinguished from each other and do they exclude one another? This question is formulated completely erroneously. Mission and ethics are not two realms of conduct that are to be divided as to their content or substance. Ethics - understood, as I have suggested, as 'implicit ethics' - attempts to elucidate the behavioural reasons, norms and arguments that constitute the implicit Pauline theory of conduct. When the reflection concerns mission, then the ethical analysis serves to deepen the understanding of Paul's mission theology. Therefore, we should not speak of 'ethics versus mission' but can better grasp the 'ethics of mission'.

\section{Acknowledgements \\ Competing interests}

The author declares that he has no financial or personal relationship(s) which may have inappropriately influenced him in writing this article.

\section{References}

Backhaus, K., 2000, 'Evangelium als Lebensraum: Christologie und Ethik bei Paulus', in U. Schnelle, T. Söding, M. Labahn \& H. Hübner (eds.), Paulinische Christologie: Exegetische Beiträge, Hans Hübner zum 70 Geburtstag, pp. 9-31, Vandenhoeck \& Exegetische Beiträge,
Ruprecht, Göttingen.

Birnbacher, D., 1995, Tun und Unterlassen, Reclam, Stuttgart.

Blischke, F., 2007, Die Begründung und Durchsetzung der Ethik bei Paulus, Evangelische Verlagsanstalt, Leipzig. (Arbeiten zur Bibel und ihrer Geschichte, 25).

Brewer, D.I., 1992, '1 Corinthians 9.9-11: A Literal Interpretation of “Do not Muzzle the Ox"', New Testament Studies 38, 554-565. http://dx.doi.org/10.1017/ S0028688500022074

Bultmann, R., [1924] 1967, 'Das Problem der Ethik bei Paulus', Zeitschrift für die neutestamentlich Wissenschaft und die Kunde der älteren Kirche 23, 123-140. Reprinted in E. Dinkler (ed.), 1967, Exegetica: Aufsätze zur Erforschung des Neuen Testaments, pp. 36-54, Mohr Siebeck, Tübingen.

Byron, J., 2003, 'Slave of Christ or willing servant? Paul's self-description in 1 Corinthians 4:1-2 and 9:16-18', Neotestamentica 36, 179-198.

Dautzenberg, G., 1969, Der Verzicht auf das apostolische Unterhaltsrecht, Biblica 50, 212-232.

Dautzenberg, G., 2001, 'Freiheit im hellenistischen Kontext', in J. Beutler (ed.), Der neue Mensch in Christus, pp. 57-81, Herder, Freiburg i. Br.

Dunn, J.D.G., 1998, The Theology of Paul the Apostle, Eerdmans, Grand Rapids.

Fotopoulos, J., 2003, Food offered to Idols in Roman Corinth: A Social-Rhetorical Reconsideration of 1 Corinthians 8:1-11:1, Mohr Siebeck, Tübingen. (Wissenschaftliche Untersuchungen zum Neuen Testament, II/151).

Galitis, G., 1981, 'Das Wesen der Freiheit: Eine Untersuchung zu 1 Kor 9', in L. de Lorenzi (ed.), Freedom and Love: The Guide for Christian Life, pp. 127-141, St. Paul's Abbey, Rome.

Harnisch, W., 2007, 'Der paulinische Lohn (I Kor 9,1-23)', Zeitschrift für Theologie und Kirche 104, 25-43. http://dx.doi.org/10.1628/004435407780034470

Hays, R.B., 1996, The Moral Vision of the New Testament. A Contemporary Introduction to the New Testament Ethics, Harper Collins, New York.

Horn, F.W. \& Zimmermann, R. (eds.), 2009, Jenseits von Indikativ und Imperativ: Kontexte und Normen neutestamentlicher Ethik/Contexts and Norms of New Testament Ethics Bd. 1, Mohr Siebeck, Tübingen. (Wissenschaftliche Untersuchungen zum Neuen Testament, 1/238).

Horrell, D., 2005, Solidarity and Difference: A Contemporary Reading of Paul's Ethics, T \& T Clark, London.
Jeremias, J., 1966, 'Chiasmus in den Paulusbriefen', in J. Jeremias (ed.), Abba: Studien zur neutestamentlichen Theologie und Zeitgeschichte, pp. 276-290, Vandenhoeck \& Ruprecht, Göttingen.

Kok, K., 2012, Aussendung, viewed n.d., from http://www.wibilex.de

Krämer, H., 1995, Integrative Ethik, Suhrkamp, Frankfurt am Main. (stw 1204).

Lührmann, D., 1986, 'Freundschaftsbrief trotz Spannungen: Gattung und Aufbau des ersten Korintherbriefs', in W. Schrage (ed.), Studien zum Text und zur Ethik des Neuen Testaments: Festschrift zum 80 Geburstag von Heinrich Greeven, pp. 298-314, de Gruyter, Berlin. (Beihefte zur Zeitschrift für die Neutestamentliche 298-314, de Gruyter,
Wissenschaft, 47).

Malherbe, A.J., 1995, 'Freedom and Determinism in Paul: The Argument in 1 Cor 9', in Engberg- T. Pedersen (ed.), Paul in His Hellenistic Context, pp. 231-255, Fortress, Minneapolis

Merk, O., 1998, 'Nachahmung Christi: Zu ethischen Perspektiven in der paulinischen Theologie', in R. Gebauer (ed.), Wissenschaftsgeschichte und Exegese, pp. 302-336, de Gruyter, Berlin. (Beihefte zur Zeitschrift für die Neutestamentliche Wissenschaft, 95).

Mitchell, M., 1991, Paul and the Rhetoric of Reconciliation: An Exegetical Investigation of the Language and Composition of 1 Corinthians, Mohr Siebeck, Tübingen. (Hermeneutische Untersuchungen zur Theologie 28).

Moore, G.E., 1970, Principia Ethica, transl. B. Wisser, Reclam, Stuttgart.

Nasuti, H.P., 1998, 'The Woes of the Prophets and the Rights of the Apostle: The Internal Dynamics of 1 Corinthians 9', Catholic Biblical Quarterly 50, 246-264.

Parsons, M., 1995, 'Being precedes Act: Indicative and Imperative in Paul's Writings', in B.S. Rosner (ed.), Understanding Paul's Ethics: Twentieth Century Approaches, pp. 217-249, Eerdmans, Grand Rapids.

Peerbolte, L.J.L., 2003, Paul the Missionary, Peeters, Leuven. (Contributions to Biblical Exegesis and Theology, 34).

Plummer, R.L., 2006, Paul's Understanding of the Church's Mission: Did the Apostle Paul Expect the Early Christian Communities to Evangelize?, Paternoster, Milton Keynes. (Paternoster Biblical Monographs).

Popovic, A., 2003, 'Freedom and Right of the Apostle: Gratis Proclamation of the Gospel as an Example of the Correct Use of Freedom and Right according to 1 Cor 9:1-18', as an Example of the Correct

Pratscher, W., 1979, 'Der Verzicht des Paulus auf finanziellen Unterhalt durch seine Gemeinden: Ein Aspekt seiner Missionsweise', New Testament Studies 25, 284-298. http://dx.doi.org/10.1017/S0028688500004926

Schlier, H., 1935, 'غ̇ $\lambda \varepsilon v ́ \theta \varepsilon \rho \varsigma^{\prime}$, Theologisches Wörterbuch zum Neuen Testament 2, 484-500.

Schnelle, U., 2003a, 'Die Begründung und die Gestaltung der Ethik bei Paulus', in R. Gebauer \& M. Meiser (eds.), Die bleibende Gegenwart des Evangeliums: Festschrift für Otto Merk zum 70. Geburtstag, pp. 109-131, N.G. Elwert, Marburg. (Marburger Theologische Studien, 76).

Schnelle, U., 2003b, Paulus: Leben und Denken, de Gruyter, Berlin.

Schrage, W., 1995, Der erste Brief and die Korinther, Neukirchener Verlag, NeukirchenVluyn. (Evangelisch-Katholischer Kommentar, VII/2).

Sundermann, H.-G., 1996, Der schwache Apostel und die Kraft der Rede: Eine rhetorische Analyse von 2 Kor 10-13, Peter Lang, Frankfurt am Main. (Evangelische Hochschul-Schriften.Theologie 575).

Theißen, G., 1979, 'Legitimation und Lebensunterhalt: ein Beitrag zur Soziologie urchristlicher Missionare', in G. Theißen (ed.), Studien zur Soziologie des
Urchristentums, pp. 201-230, Mohr Siebeck, Tübingen. Reprint of 1975,

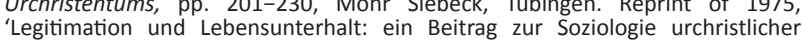
Missionare', New Testament Studies 21, 192-221. (Wissenschaftliche Missionare', New Testament Studies 21,
Untersuchungen zum Neuen Testament, 19).

Theißen, G., 2002, 'Zum Freiheitsverständnis bei Paulus und Philo: Paradoxe und kommunitäre Freiheit', in H.-R. Reuter (ed.), Freiheit verantworten: Festschrift für Wolfgang Huber zum 60 Geburtstag, pp. 357-368, Gütersloher Verlag, Gütersloh.

Vollenweider, S., 1989, Freiheit als neue Schöpfung: Eine Untersuchung zur Eleutheria bei Paulus und in seiner Umwelt, Vandenhoeck \& Ruprecht, Göttingen. (Forschungen zur Religionsgeschichte des Alten und Neuen Testaments, 147).

Ware, J.P., 2005, The Mission of the Church in Paul's Letter to the Philippians in the Context of Ancient Judaism, Brill, Leiden. (Novum Testamentum. Supplementum, 120)

Wolff, C., 1990, Der erste Brief des Paulus an die Korinther, Leipzig. (Theologischer Handkommentar zum Neuen Testament, VII/2).

Wolter, M., 2009, 'Identität und Ethos bei Paulus', in M. Wolter (ed.), Theologie und Ethos im frühen Christentum: Studien zu Jesus, Paulus und Lukas, pp. 121-169, Mohr Siebeck, Tübingen. (Wissenschaftliche Untersuchungen zum Neuen Testament, 236)

Wolter, M., 2011, 'Die Ethik', in M. Wolter (ed.), Paulus. Ein Grundriss seiner Theologie, pp. 308-338, Neukirchener Verlag, Neukirchen-Vluyn.

Zeller, D., 2010, Der erste Brief an die Korinther, Vandenhoeck \& Ruprecht, Göttingen. (Kritisch-Exegetischer Kommentar, 5).

Zimmermann, R., 2007, 'Jenseits von Indikativ und Imperativ: Entwurf einer "impliziten Ethik" des Paulus am Beispiel des 1. Korintherbriefes', Theologische Literaturzeitung 132, 259-284.

Zimmermann, R., 2009, 'The "Implicit Ethics" of New Testament Writings: A Draft on a New Methodology for Analysing New Testament Ethics', Neotestamentica 43, 399-423.

Zimmermann, R., 2010, 'Ethics in the New Testament and Language: Basic explorations and Eph 5:21-33 as Test Case', in R. Zimmermann \& J.G. van der Watt (eds.), Moral Language in the New Testament: The interrelatedness of Language and Ethics in Early Christian Writings, Contexts and Norms of New Testament Ethics Vol. II, pp. 19-50, Mohr Siebeck, Tübingen. (Wissenschaftliche Untersuchungen zum Neuen 19-50, Mohr Siebeck,
Testament, II/296). 